\title{
Frequency of Antibiotic Resistance of Escherichia Coli and Klebsiella Pneumoniae by Production of TOHO-type $\beta$-lactamases at Saint Camille Hospital, Ouagadougou (Burkina Faso)
}

Serge Sougué ( $\nabla$ sergesougue@yahoo.fr)

University of Ouagadougou: Universite de Ouagadougou

Amana Mètuor-Dabiré

University of Dédougou

Djéneba Ouermi

University of Ouagadougou: Universite de Ouagadougou

Yasmine Rahimatou Wend-Kouni Tiemtoré

University of Ouagadougou: Universite de Ouagadougou

Théodora Mahoukèdè Zohoncon

University of Saint Thomas Aquinas

Yasmine Aminata Bangré

University of Ouagadougou: Universite de Ouagadougou

Elie Kabré

National Public Health Laboratory of Ouagadougou

Jacques Simporé

University of Ouagadougou: Universite de Ouagadougou

Research

Keywords: Antibiotic, Resistance, Bacteria; ESBL, Genes, TOHO

Posted Date: November 2nd, 2020

DOI: https://doi.org/10.21203/rs.3.rs-97786/v1

License: (c) (i) This work is licensed under a Creative Commons Attribution 4.0 International License.

Read Full License 


\section{Abstract}

Background: Extended-spectrum $\beta$-lactamase (ESBL) appeared some years after the introduction in hospital environment of unhydrolysable or extended-spectrum cephalosporins. Several studies have been reported on the blaTEM, blaCTX-M and blaSHV genes in ESBL producing Enterobacteria, however very few studies reported in the literature are related to blaCTX-M subgroup blaTOHO. TOHO enzymes were responsible for healthcare-associated infections in hospitals and in the community. In Burkina Faso, data related to these types of enzymes were scarce. The purpose of this study was to detect TOHO enzymes in Escherichia coli and Klebsiella pneumoniae in order to know the prevalence of infections related to bacterial resistance due to TOHO enzymes at Saint Camille Hospital of Ouagadougou (Burkina Faso).

Materials and methods: The study was conducted firstly by microbiological identification of ESBLproducing by Escherichia coli and Klebsiella pneumoniae using API 20 E gallery; secondly the antibiogram was performed by the diffusion method and finally the molecular characterization was made by conventional PCR to search for the bla ${ }_{\text {Tоно }}$ gene. The visualization of the specific bands was made using the ultraviolet lamp (Gene Flash) for the photography of the gels. Data were entered and analyzed using Excel 2013 and EPI Info version 6.0 software. A p-value $<0.05$ was considered as significant.

Results: We obtained at all 39 strains constituted by 21 (53.8\%) Escherichia coli and 18 (46.2\%) Klebsiella pneumoniae. Molecular characterization showed the presence of the bla ${ }_{\mathrm{TOHO}}$ gene in 25 bacterial strains (64.1\%).

Conclusion: It was therefore established in this study the existence of $b / a_{\mathrm{TOHO}}$ gene at Saint Camille Hospital in Ouagadougou in Burkina Faso. Our study made it possible to know the distribution of the blaTOHO gene in Escherichia coli and Klebsiella pneumoniae.

\section{Background}

Antimicrobial resistance became a threat to public health. It constitutes a growing danger to human health in the whole world; but the hospital has always been considered like the most important risk holder (Bradford PA et al. 2001).

Thereby, the first antimicrobial resistance surveillance data published by the World Health Organization (WHO, 2018) showed high levels of resistance to several serious bacterial infections in both high and low income countries. Antimicrobial resistance is responsible for about 700,000 deaths a year worldwide and has huge implications for the cost of healthcare (Jasovsky et al. 2016). The production of ExtendedSpectrum $\beta$-lactamase (ESBL) by Enterobacteria is the main mechanism of the antimicrobial resistance. Several studies have been conducted on the major genes involved in the production of ESBLs. The most common ESBLs are the Temoneira (TEM), Variable sulfhydryl (SHV) and Cefotaximase-Munich (CTX-M) types (Sadeeq et al. 2018). 
The first plasmid TEM-1-type $\beta$-lactamase was isolated in 1965 in Greece from a strain of $E$. coli isolated in a patient named Temoneira hence the name (Zubair et al. 2015). The SHV-types ESBL are derived by punctual mutations from the original SHV-1 enzyme, which corresponds to a $K$. pneumoniae chromosomal penicillinase bla $a_{S H V}$ gene (Brisse and Verhoef 2001; Haeggman et al. 2004). Currently, more than 180 SHV ESBL variants have been described (Liakopoulos et al. 2016). CTX-M ESBLs were initially described in 1986 in Japan, Germany and France in 1989 (CTX-M-1) and have since spread widely around the world (Thomson and Moland 2000). CTX-M is the most prevalent ESBLs worldwide (Paterson et al. 2005).

The CTX-M group (for cefotaximase) originally gave enterobacteria a higher level of resistance to Cefotaxime, Ceftriaxone, Cefepime and Aztreonam than to Ceftazidime (Arlet and Philippon. 2003; Bonnet. 2004). Some of them have evolved more recently by mutation (ponctual or not) generating a high level of resistance to Ceftazidime such as the CTX-M-15, CTX-M-16, CTX-M-19, CTX-M- 23 and CTX-M-32 enzymes (Bonnet. 2004). Recently, more than 150 variants of CTX-M have been described and classified into 6 phylogenetic groups: the CTX-M-1 group; CTX-M-2 and Toho-1 group; the CTX-M-8 group; the CTXM-9 group, the CTX-M-25 group and finally the CTX-M-45 group. These new ESBLs were not closely related to TEM or SHV $\beta$-lactamases since they only showed $40 \%$ homology with these classic ESBLS (Elhani. 2012). Horizontal dissemination of the genes coding for the CTX-M enzymes occurs via conjugative plasmids but also via other genetic elements such as integrons and ISEcp1 insertion sequences (Bradford. 2001).

Besides the so-called major ESBLs, there were minor types ESBLs such as TOHO-type, BES-type, Pseudomonas extended Resistance (PER) type, Vietnam extended-spectrum $\beta$-lactamase (VEB) type, Guiana extended-spectrum $\beta$-lactamase (GES) type, TEM Like Activity (TLA) type, Serratia fonticola (SFO) type which were less studied (Cattoir V, 2008). TOHO-type is a variant of CTX-M2c (Andres et al. 2005). The bla $a_{\mathrm{TOHO}}$ gene has been described for the first time at Toho University School of Medicine (Japan) in the urine of a one-year-old girl in E. coli TUH12191 (Ishii et al. 1995). This gene has been notified in the first time in Argentina in Shigella flexneri in the stool of a 33-year-old woman (Andres et al. 2005).

TOHO-2 ESBL have also been described as produced by E. coli TUH1083. It was categorized as an enzyme similar to TOHO-1 group $\beta$-lactamase rather than to mutants of TEM or SHV enzymes (Ling et al. 1998). The prevalence of the $b / a_{\text {Tоно }}$ gene in ESBL-producing Enterobacteria has not been reported in the literature yet. Investigations work on $\beta$-lactamases at Burkina Faso scale were relatively recent and have already identified the presence of TEM, SHV and CTX-M genes, which are responsible for bacterial resistance in enterobacteria (Zongo et al. 2015).

This study was undertaken with the aim of detecting the bla $a_{\mathrm{TOHO}}$ gene in ESBLs-producing by Escherichia coli and Klebsiella pneumoniae at Saint Camille Hospital of Ouagadougou (Burkina Faso).

\section{Methods}




\subsection{Type of study}

It was a cross-sectional study conducted at Saint Camille Hospital in Ouagadougou (Burkina Faso) from September to November 2018. Samples collected consisted of stool samples, urine samples and vaginal swab samples from hospitalized patients or out-patients. Samples were inoculated on common media like Uri Select medium, Hektoen medium and Salmonella Shigella (SS) medium to allow Enterobacteria growth and then incubated for 24 hours at $37^{\circ} \mathrm{C}$. Subsequently, Enterobacteria that grew on the previous media were subcultured on a Mueller-Hinton $(\mathrm{MH})$ medium and then incubated for 24 hours at $37^{\circ} \mathrm{C}$ for antimicrobial analysis (Gaillot $O$ et al. 1999).

\subsection{Antimicrobial essays}

The bacterial strains were identified using Analytical Profile Index (API 20 E) Identification method.

Antibiotic susceptibility and resistance test were carried out on Mueller-Hinton (MH) medium with pure colonies of Escherichia coli and Klebsiella pneumoniae according to the recommendations of the Committee of antibiogram of the French Society of Microbiology (CASFM/EUCAST 2018). The antibiotic discs used were: Amoxicillin + Clavulanic acid (Augmentin), Cefotaxime, Ceftazidime, Ceftriaxone and Aztreonam. All Augmentin resistant Escherichia coli and Klebsiella pneumoniae and at least one third generation cephalosporin were considered in this study as ESBL producing Escherichia coli and Klebsiella pneumoniae (Amana et al. 2019).

\subsection{Molecular characterization of ESBLs 5.3.1. Bacterial DNA extraction}

The boiling method was used to extract DNAs from bacteria (Ribeiro Junior JC, et al. 2016). The strains were reactivated by culturing on the $\mathrm{MH}$ medium for 18-24 hours. An isolated colony was taken from the Petri dish and suspended in $200 \mu \mathrm{l}$ of distilled water previously aliquoted in labeled Eppendorf tubes, then followed by immersion in a water bath at $100{ }^{\circ} \mathrm{C}$ for $15 \mathrm{~min}$ to release the genetic material. After immersion in a water bath, the suspension was centrifuged at 12,000 rpm for 10 minutes and the supernatant containing DNA released was transferred to a new Eppendorf tube. The concentration of the DNA was then determined using the Nanodrop-type spectrophotometer (BioDrop UV/Vis DUO, Holliston, USA).

\subsubsection{Molecular analysis}

The reaction medium for PCR was constituted by a volume of $25 \mu \mathrm{l}$ composed of the Master Mix, the DNA and the primers for $b / a_{\text {Tоно }}$. PCR program consisted of an initial denaturation at $95^{\circ} \mathrm{C}$ for 5 minutes followed by 30 cycles (Denaturation $95^{\circ} \mathrm{C} / 59 \mathrm{~s}$, Annealing $50^{\circ} \mathrm{C} / 59 \mathrm{~s}$, Elongation $68^{\circ} \mathrm{C} / 59 \mathrm{~s}$ ) and a final Extension at $68^{\circ} \mathrm{C}$ for 5 minutes. We used Gene Amp Thermocycler PCR System 9700.

PCR amplification of bla $a_{\mathrm{TOHO}}$ gene was carried out with specific primers provided by Applied Biosystems :

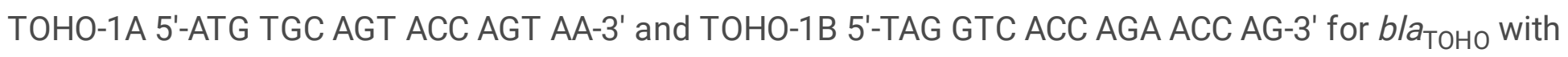




\subsubsection{Electrophoresis on agarose gel}

Agarose gel (1\%) for electrophoresis was prepared with 1X TBE buffer with addition of $8 \mu$ Ethidium bromide (BET) $0.5 \mu \mathrm{g} / \mathrm{ml}$ which allowed visualization of the bands in the UV light. An electrophoretic migration at 110 millivolts for 30 minutes was performed on the PCR products using a molecular weight marker (1 kb). The fragments were visualized under UV light (Gene Flash) and the images were recorded (Lee PY et al. 2012).

\subsection{Data processing}

The clinical data was entered in Excel 2013 and then analyzed with the Standard Statistical Package for Social Sciences (SPSS) version 17.0 for Windows and the EPI Info version 6.0 software. All tests of significance were considered statistically significant at P-value < 0.05 (WHO, 2019).

\section{Results}

We have found at total 16 stools, 22 urines and 1 vaginal swab samples positive to Escherichia coli and Klebsiella pneumoniae. All samples had shown an antibiotic resistance profile by ESBL production (Fig. 1). Among them 15 patients were male and 24 were female, with a sex ratio of 0.63 . The ages were ranged from 22 days to 95 years with an average age of 38 years. There were 20 hospitalized patients and 19 out-patients.

Results for the sensitivity/resistance of the 39 bacterial isolates to the different antibiotics tested showed that 26 strains $(66.7 \%)$ were resistant to Cefotaxime, 28 strains $(71.8 \%)$ were resistant to Ceftriaxone, 25 strains (64.1\%) were resistant to Aztreonam and 20 strains (51.3\%) were resistant to Ceftazidime as shown in the table I. The table II showed the frequency of Escherichia Coli and Klebsiella pneumonia involved in bacterial resistance in the study. We notice that all strains were resistant to Amoxicillin + Clavulanic acid (Augmentin®).

\section{Table I}

Resistance profile of different strains to antibiotics used

\begin{tabular}{|lccccc|}
\hline Bacterial strains & \% ATM & \% CAZ & \% CTX & \% CTR & \% Synergy image \\
\hline Escherichia coli & 33.3 & 30.8 & 38.5 & 38.5 & 5.1 \\
\hline Klebsiella pneumoniae & 30.8 & 20.5 & 28.2 & 33.3 & 2.6 \\
\hline $\begin{array}{l}\text { Legend } \\
\text { ATM = Aztreonam, CTX = Cefotaxime, CTR = Ceftriaxone, CAZ = Ceftazidime }\end{array}$ &
\end{tabular}


Distribution of strains involved in bacterial resistance by ESBL production

\begin{tabular}{|lll|}
\hline Bacterial species & Numbers & Frequency (\%) \\
\hline Escherichia coli & 21 & 53.8 \\
\hline Klebsiella pneumonia & 18 & 46.2 \\
\hline Total & 39 & 100 \\
\hline
\end{tabular}

Molecular characterization of the ESBLs by PCR revealed that 25 (64.1\%) strains isolated from patients at Saint Camille Hospital of Ouagadougou (HOSCO) carried the b/a $\mathrm{TOHO}_{\mathrm{HO}}$ gene as shown by the electrophoresis bands (Fig. 2).

\section{Discussion}

In this report, we mentioned the occurrence of several Escherichia and Klebsiella strains carrying the bla $a_{\text {Тоно }}$ gene (table III). In order to conduct molecular epidemiology study of $b / a_{\mathrm{TOHO}}$ gene conventional PCR with electrophoresis on agarose gel has been shown to be useful with their sensibility and specificity.

In terms of predominance of certains strains responsibles of antibiotic resistance it has been found at Laghouat Hospital (Algeria): 43\% Escherichia coli and 30\% Klebsiella pneumoniae (Lagha et al. 2015). Other studies; that were done at the Charles De Gaulle Paediatric Teaching Hospital (CHUP / CDG) of Ouagadougou (Burkina Faso), showed $47.22 \%$ for Escherichia coli; $15.55 \%$ for Klebsiella pneumoniae and $3.33 \%$ for Klebsiella oxytoca (Mètuor-Dabiré A, 2014).

The types of ESBLs found in these studies were CTX-M, SHV and TEM. The prevalence of ESBLs produced by Escherichia coli and Klebsiella pneumoniae were also described in South America (45.451.9\%) (Villegas MV et al. 2008) and Saudi Arabia (55\%) (Al-Agamy et al. 2009).

These results confirm that the overall prevalence of ESBLs production by Enterobacteria fluctuates considerably according to the geographical zones, to the countries and to different hospitals. However, the bacterial strains mainly concerned by antibiotic resistance were $E$. coli and $K$. pneumoniae with the high level of ESBL production (Lagha N, 2015; Villegas MV et al. 2008).

The antibiotic susceptibility profile of the 39 strains tested showed resistance to most of $\beta$-lactams antibiotics. These levels of antibiotic resistance in the study could be explained by the misuse of antibiotics. It is currently proved that the use of antibiotics, including third-generation cephalosporin for therapeutic purposes is the most important risk factor in the development of bacterial resistance (MètuorDabiré A, 2014). Other types of resistance mechanisms could explain these levels of antibiotic resistance like the modification of the membrane permeability, the modification of the antibiotic target, the metabolic pathway change or the efflux phenomena (Munita JM et al. 2016). 
The molecular characterization of the 39 bacterial strains by PCR showed the TOHO type ESBL in 25 (64.1\%). TOHO-1 enzymes have been described for the first time in Japan and were structurally very close to CTX-M and are therefore classified among this group (Tetsuya et al. 1997; Bonnet et al. 2004). This type of ESBL (CTX-M) is frequently encountered in hospitals (Paterson et al. 2005). This could explain the high prevalence of TOHO enzymes in our study. The first detection of TOHO-1 outside Japan was reported in a strain of Shigella flexneri in the stool of a 33-years-old woman in Argentina (Andres et al. 2005). This bacterial strain expressed an enzyme belonging to CTXM2c whose DNA sequencing gave TOHO-1.

There were two types of TOHO enzymes (TOHO-1 and TOHO-2) and their precise prevalence has never been reported in an epidemiological study and the truth of the sequence has been questioned because it was so closely related to CTX-M-2 (Hawkey PM et al. 2008). TOHO-1 was an ESBL that has achieved efficient activity not only against penicillins but also against third-generation cephalosporins (Tatsuro et al. 2002). TOHO-2 was reported in Tokyo (Japan) in E. coli isolated from the urine of a $\beta$-lactam treated patient (Ling et al. 1998).

This high prevalence of the $b / a_{\text {TOHO }}$ gene in our study about antibiotic-resisting bacterial strains could also be explained by a spread of this gene in Africa and at Saint Camille Hospital in Ouagadougou, HOSCO (Burkina Faso).

\section{Table III}

Prevalence of the bla $a_{\mathrm{TOHO}}$ gene according to bacterial species

\begin{tabular}{|ll|}
\hline Bacterial species & TOHO gene \\
\hline Escherichia coli & 14 \\
\hline Klebsiella pneumoniae & 13 \\
\hline Total & 25 \\
\hline $\begin{array}{l}\text { The distribution of the bla }{ }_{\text {TOHO }} \text { gene according to the bacterial species (Escherichia coli and Klebsiella } \\
\text { pneumoniae). }\end{array}$ \\
\hline
\end{tabular}

\section{Conclusion}

The objective of this work was to detect Escherichia coli and Klebsiella pneumoniae producing TOHOtype ESBL at Saint Camille Hospital of Ouagadougou (Burkina Faso).

This study revealed that alongside the CTX-M, TEM and SHV genes, there were other once rare types such as TOHO which was a subgroup of CTX-M found in Escherichia coli and Klebsiella pneumoniae. 
This molecular epidemiological study found the b/a $a_{\text {Тоно }}$ gene in 25 bacterial strains (64.1\%) carried by patients in hospitals of Burkina Faso and particularly at Saint Camille Hospital of Ouagadougou.

\section{Abbreviations}

API: Analytical profil index

ATM: Aztreonam

CAZ: Ceftazidime

CERBA: Pietra Annigonni Biomolecular Research Centre

CHUP / CDG: Charles De Gaulle Paediatric Teaching Hospital of Ouagadougou

CTR: Ceftriaxone

CTX: Cefotaxime,

CTX-M: Cefotaximase-Munich

EUCAST: European committee on antimicrobial susceptibility testing

HOSCO: Saint Camille Hospital of Ouagadougou

LABIOGENE : Laboratory of Biology and Genetics Molecular

SHV: Variable sulfhydryl

TBE: Tris-borate-EDTA

TEM: Temoneira

USTA: Saint Thomas Aquina University

UV : Ultra-violet

\section{Declarations}

\section{Ethical Approval and Consent to participate}

This study received the approval of the CERBA's internal ethics committee

\section{Consent for publication}




\section{Availability of supporting data}

"Not applicable"

\section{Conflict of Interest}

The authors have no conflict of interest to declare.

\section{Funding}

"Not applicable"

\section{Authors' contribution}

Serge Sougué and Amana Mètuor-Dabiré, study concept and design, acquisition of data, analysis and interpretation of data, writing the manuscript. Yasmine Rahimatou Wend-Kouni Tiemtoré, Serge Sougué and Yasmine Aminata Bangré, specimens collection and Laboratory investigations under the guidance of Amana Mètuor-Dabiré. Théodora Zohoncon, specimens and clinical information collection as well as patients follow up. Jacques Simporé, study concept and design and preparation of the manuscript. All the authors have read and approved the final manuscript.

\section{Acknowledgments}

We thank the entire staff of Saint Camille Hospital in Burkina Faso, Ouaga 1 Pr Joseph KI-Zerbo University in Burkina Faso, University of Dedougou in Burkina Faso and National Public Health laboratory in Burkina Faso which actively participated in the realization of this work.

\section{References}

1. Al-Agamy MH, Shibl AM, Tawfik AF. Prevalence and molecular characterization of extended-spectrum beta-lactamase-producing Klebsiella pneumoniae in Riyadh, Saudi Arabia. Ann Saudi Med. 2009;29(4):253-7. https://www.ncbi.nlm.nih.gov/pubmed/19587523.

2. Amana MD, Serge $S$, Wend-Kuni TRY, Mahoukèdè $Z T$, Aminata BY, Paul $O$, Elie $K$, Jacques $S$. Coexistence between (TOHO-type and BES-type) extended-spectrum $\beta$-lactamase genes of identified enterobacteria at Saint Camille Hospital, Ouagadougou, West Africa. International Journal of 
Genetics Molecular Biology. 2019;11(2):34-40.

https://academicjournals.org/journal/IJGMB/A31A5C562415.

3. Andres P, Petroni A, Faccone D. Extended-spectrum $\beta$-lactamases in Shigella flexneri from Argentina: first report of TOHO-1 outside Japan. Int J Antimicrob Agents. 2005;25:501-7. https://www.ncbi.nlm.nih.gov/m/pubmed/15878653.

4. Arlet G. Les nouvelles $\beta$-lactamases à l'aube du troisième millénaire. Rev Franç Lab. 2003;352:4155., and Philippon, A. https://www.sciencedirect.com/science/article/pii/S1294550105804583.

5. Bonnet R. (2004). Growing group of extended-spectrum-beta-lactamases: the CTX-M enzymes. Antimicrob. Agents Chemother. 48: 1-14. http://europepmc.org/articles/pmc310187.

6. Bradford PA. (2001) "Extended-spectrum $\beta$-lactamases in the 21st century: characterization, epidemiology and detection of this important resistance threat". Clinical Microbiology Reviews, 14.4 (2001): 933-951. https://www.ncbi.nlm.nih.gov/pmc/articles/PMC89009.

7. Brisse S, et Verhoef J. Phylogenetic diversity of Klebsiella pneumoniae and Klebsiella oxytoca clinical isolates revealed by randomly amplified polymorphic DNA, gyrA and parC genes sequencing and automated ribotyping. Int J Syst Evol Microbiol. 2001;51:915-24. https://www.researchgate.net/publication/11927778.

8. CASFM/EUCAST,. (2018). Antibiotic Committee of the French Microbiology Society, Recommendation 2018. http://www.sfm.asso.fr.

9. Cattoir V. (2008). Les nouvelles $\beta$-lactamases à spectre étendu (BLSE). http://www.mapar.org/article/1/Communication.

10. Elhani D. 2012. Les bêta-lactamases à spectre étendu: le défı s'accentue. Ann Biol Clin. 70(2). 117140. https://pdfs.semanticscholar.org/223b/d4c5edfb859b0ccfa9d8b20cd57ff84ee08c.pdf.

11. Gaillot O, Camillo PD, Berche P, Courcol R, Savage C (1999) Comparison of CHROMagar Salmonella Medium and Hektoen Enteric Agar for Isolation of Salmonellae from Stool Samples. J Clin Microbiol, 37, No. 3. 762-5. https://www.ncbi.nlm.nih.gov/pmc/articles/PMC84546.

12. Hæggman S, Lofdahl S, Paauw A, Verhoef J, Brisse S. Diversity and evolution of the class A chromosomal beta-lactamase gene in Klebsiella pneumoniae. Antimicrob Agents Chemother. 2004;48(7):2400-8. https://www.ncbi.nlm.nih.gov/pmc/articles/PMC434173.

13. Hawkey PM. Prevalence and clonality of extended-spectrum $\beta$-lactamases in Asia. Clinical Microbiology Infection. 2008;14:159-65. https://www.clinicalmicrobiologyandinfection.com/article/S1198-743X. (14)60487-0/fulltext.

14. Ishii Y, Akira O, Hayao T. (1995). Cloning and Sequencing of the Gene Encoding a CefotaximeHydrolysing Class A $\beta$-lactamase Isolated from Escherichia coli. American Society for Microbiology. 39(10): 2269-2275. https://aac.asm.org/content/aac/39/10/2269.full.pdf.

15. Jasovsky D, Littmann J, Zorzet A, Cars O. Antimicrobial resistance a threat to the world's sustainable developpement. Upsala J Med Sci. 2016;121(3):159-64.

https://www.ncbi.nlm.nih.gov/pmc/articles/PMC4967260. 
16. Lagha N. (2015). Antibiotic resistance study of extended spectrum $\beta$-lactamase-producing Enterobacteriaceae (ESBL) isolated from Laghouat Hospital: Alger. .

17. Laurent $P$, Isabelle LT, Thierry N, Amal K, Patrice N. Biochemical Sequence Analyses of GES-1, a Novel Class A Extended-Spectrum $\beta$-Lactamase, and the Class 1 Integron In52 from Klebsiella pneumoniae. Antimicrob Agents Chemother. 2000;44(3):622-32.

https://www.ncbi.nlm.nih.gov/pubmed/10681329.

18. Lee PY, Costumbrado J, Hsu CY, Kim YH. (2012) Agarose Gel Electrophoresis for the Separation of DNA Fragments. Journal of Visualized Experiments (62), e3923. https://www.ncbi.nlm.nih.gov/pubmed/22546956.

19. Liakopoulos A, Ceccarelli MD D. (2016). "A Review of SHV Extended-Spectrum $\beta$-Lactamases: Neglected Yet Ubiquitous". Front. Microbiol. 7 (2016):1374 https://www.ncbi.nlm.nih.gov/m/pubmed/27656166.

20. Ling M, Yoshikazu I, Masaji I. Cloning and Sequencing of gene Encoding Toho-2, a Class A $\beta$ lactamase Preferentially Inhibited by Tazobactam. American Society for Microbiology. 1998;42(5):1181-6. https://www.ncbi.nlm.nih.gov/pmc/articles/PMC105770.

21. Mètuor-Dabiré A. (2014). Molecular and kinetic characterization of broad-spectrum $\beta$-lactamase (ESBL) types of bacterial strains collected at the Pediatric University Hospital Charles De Gaulle (CHUP-CDG): Ouagadougou. .

22. Munita JM, Arias CA. (2016) Mechanisms of Antibiotic Resistance, Microbiol Spectr. 4(2): https://www.ncbi.nlm.nih.gov/pmc/articles/PMC4888801.

23. Paterson DL, Bonomo RA. Extended-spectrum $\beta$-lactamases: a clinical update. Clin Microbiol Rev. 2005;18(4):657-86. https://www.ncbi.nlm.nih.gov/pubmed/16223952.

24. Ribeiro Junior JC, Tamanini R, Soares BF, Marangon de Oliveira A, Silva F. Efficiency of boiling and four other methods for genomic DNA extraction of deteriorating spore-forming bacteria from milk. Agricultural Sciences. 2016;37:(5) 3069-78. http://www.uel.br/revistas/uel/index.php/semagrarias/article/view/24630.

25. Sadeeq U. R.,TariqA., Ijaz A., Nazir A. K., Bo H. and Jian G. (2018) The growing genetic and functional diversity of Extended spectrum beta-lactamases, Biomed Research International, Volume 2018, Article ID 9519718, 14 pages. https://www.hindawi.com/journals/bmri/2018/9519718

26. Tatsuro S, Akiko I, Shinya F, Takayoshi W, Masaji I, Ishii Y, Hiroshi M. Acyl-intermediate Structures of the Extended-spectrum Class A $\beta$-lactamase, Toho-1, in Complex with Cefotaxim, Cephalothin, and Benzylpenicillin. the journal of biological chemistry. 2002;277(48):46601-8. http://www.jbc.org/content/277/48/46601.full.

27. Tetsuya Y, Hiroshi K, Kazuyoshi S. Nosocomial Spread of Cephem-Resistant Esherichia coli Strains Carrying Multiple Toho-1-Like $\beta$-lactamase Genes. American Society for Microbiology. 1997;41(12):2606-11. https://www.ncbi.nlm.nih.gov/pmc/articles/PMC164177.

28. Thomson KS, Moland ES. The new $\beta$-lactamases of Gram negative bacteria at the dawn of the new millennium. Microbes Infect. 2000;2:1225-35. https://www.ncbi.nlm.nih.gov/pubmed/11008112. 
29. Villegas MV, Kattan JN, Quinteros MG, Casellas JM. Prevalence of extended-spectrum $\beta$-lactamases in South America. Clin Microbiol Infect. 2008;14:154-8. https://www.sciencedirect.com/science/article/pii/S1198743X14604869.

30. WHO. (2019). Instructions for data-entry and data-analysis using Epi Info ${ }^{\mathrm{TM}}$, https://www.who.int/gpsc/5may/epi_info_instructions.pdf.

31. WHO. 2018. High levels of antibiotic resistance found worldwide, new data shows. https://www.who.int/news-room/detail/29-01-2018.

32. Zongo KJ, Dabire AM, Compaore LG, Sanou I, Sangare L, Simpore J, Zeba B. First detection of bla TEM, SHV and CTX-M among Gram negative bacilli exhibiting extended spectrum $\beta$-lactamase phenotype isolated at University Hospital Center, Yalgado Ouedraogo, Ouagadougou, Burkina Faso. Afr J Biotech. 2015;14(14):1174-80. .

33. Zubair M, Malik A, Ahmad J. Microbiology of Diabetic Foot Ulcer with Special Reference to ESBL Infections. American Journal of Clinical Experimental Medicine. 2015;3(1):6-23. http://www.sciencepublishinggroup.com/j/ajcem.

\section{Figures}




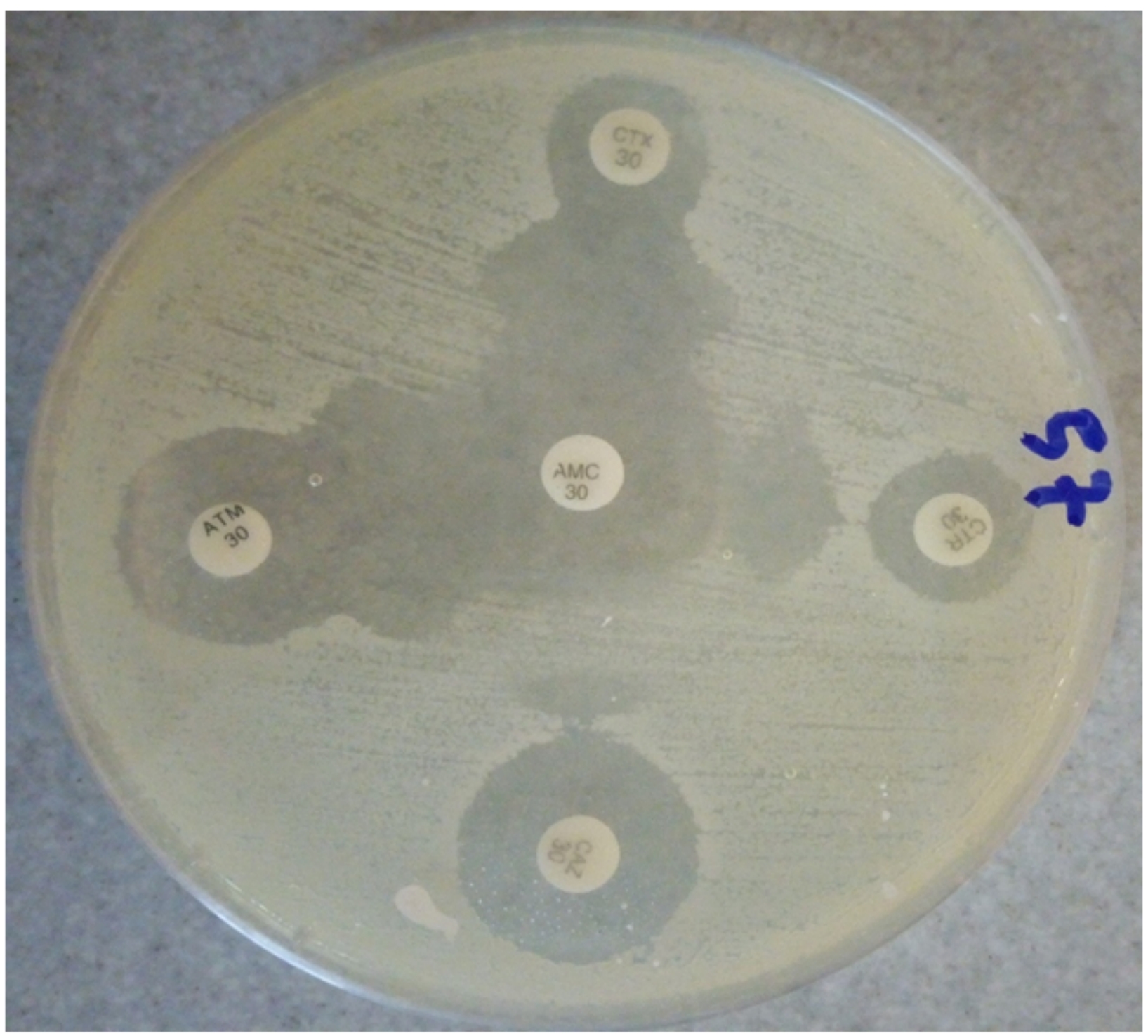

\section{Figure 1}

Petri dish representing a synergy image characteristic of ESBL producing by Escherichia coli strain 


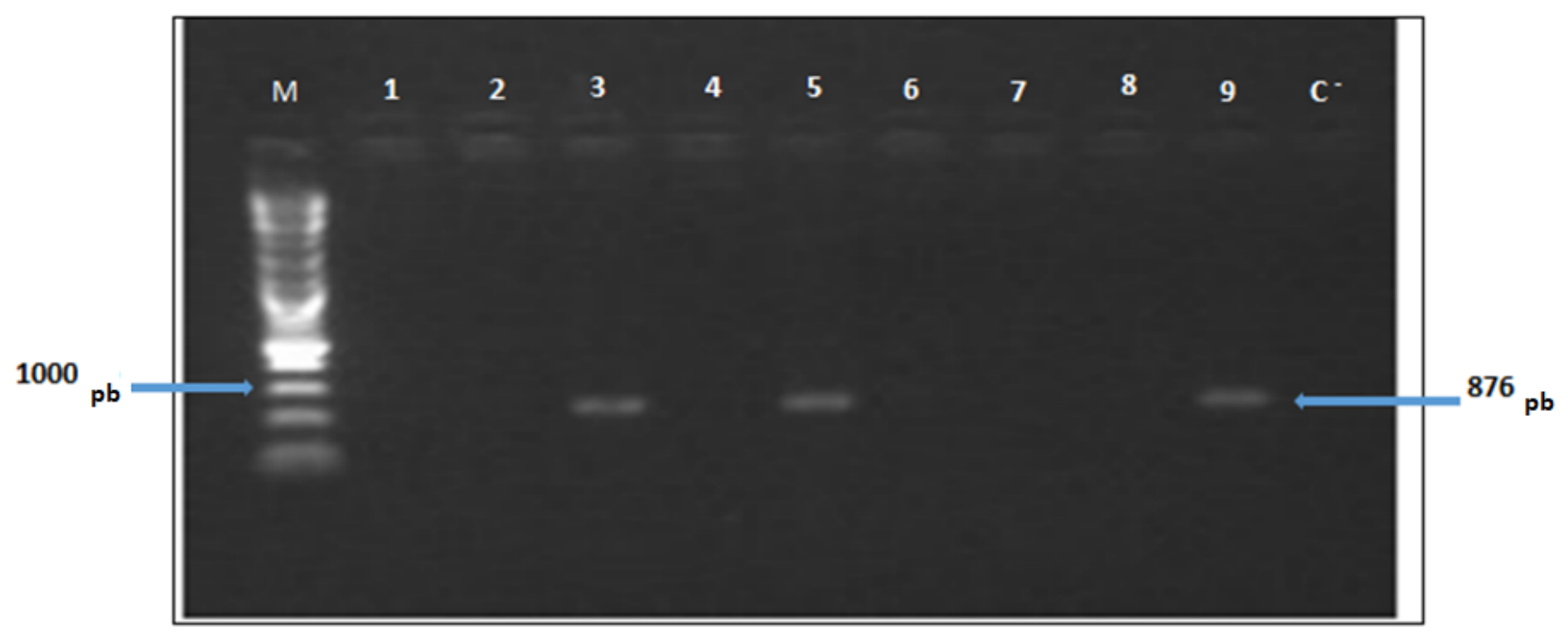

Figure 2

Agarose gel image showing PCR products of blaTOHO genes in identified isolates Legend : Lane $(\mathrm{M})=$ Molecular Weight Marker (DNA Ladder (1kb)); Lanes (1-9) = Samples; Lane (C-) = negative control ; Lanes 3,5 and $9=$ positive to blaTOHO gene 